\title{
Pollen morphology of some Fabaceae species from Patos de Minas, Minas Gerais State, Brazil ${ }^{1}$
}

\author{
Higor Antonio-Domingues ${ }^{2,5}$, Angela Maria da Silva Corrêa ${ }^{2}$, Rubens Teixeira de Queiroz ${ }^{3}$ and \\ Norma Aparecida Borges Bitar ${ }^{4}$
}

Received: 25.08.2017; accepted: 19.12.2017

\begin{abstract}
Pollen morphology of some Fabaceae species from Patos de Minas, Minas Gerais State, Brazil). This paper presents a palinologycal study of 16 Fabaceae species (Bauhinia variegata (L.), Caesalpinia echinata Lam., C. pulcherri$m a$ (L.) Sw., Calliandra surinamensis Benth., Cassia grandis L. f., Delonix regia (Bojer ex Hook.) Raf., Inga vera Willd., I. laurina (Sw.) Willd., Mimosa caesalpiniifolia Benth., M. pudica L., Myroxylon peruiferum L. f., Platypodium elegans Vogel, Poincianella pluviosa (DC.) L.P. Queiroz, Senna multijuga (Rich.) H.S. Irwin \& Barneby, S. polyphylla (Jacq.) H.S. Irwin \& Barneby and Senna trachypus (Mart. ex Benth.) H.S. Irwin \& Barneby), which occur in the Centro Universitário de Patos de Minas Campus I- UNIPAM, and in the urban area of the city. The results showed that Fabaceae is euripalinous, displaying small, medium, large and very large sized pollen grains, dispersed in monads, tetrads and polyads, 3-colporate, 3-colpate, 4-(5)-(6)-24-porate, and with psilate, rugulate, reticulate-rugulate, retipilate to striate-reticulate sexine.
\end{abstract}

Keywords: Cerrado, Landscaping, Leguminosae, Palinology, Urban area

RESUMO - (Morfologia polínica de algumas espécies de Fabaceae de Patos de Minas, MG, Brasil). Esse trabalho apresenta o estudo palinológico de 16 especies de Fabaceae (Bauhinia variegata (L,.), Caesalpinia echinata Lam., C. pulcherrima (L.) Sw., Calliandra surinamensis Benth., Cassia grandis L. f., Delonix regia (Bojer ex Hook.) Raf., Inga vera Willd., I. laurina (Sw.) Willd., Mimosa caesalpiniifolia Benth., M. pudica L., Myroxylon peruiferum L. f., Platypodium elegans Vogel, Poincianella pluviosa (DC.) L.P. Queiroz, Senna multijuga (Rich.) H.S. Irwin \& Barneby, S. polyphylla (Jacq.) H.S. Irwin \& Barneby e Senna trachypus (Mart. ex Benth.) H.S. Irwin \& Barneby) ocorrentes no Centro Universitário de Patos de Minas Campus I - UNIPAM e na área urbana da cidade. Os resultados demonstraram que Fabaceae é uma família euripolinica, com grãos de pólen pequenos, médios, grandes e muito grandes, com unidades de dispersão em mônades, tétrades e políades, 3-colporados, 3-colpados, 4-(-5)-(6)-24-porados, com sexina psilada, rugulada, reticulado-rugulada, retipilada a estriado-reticulada.

Palavras-chave: Área Urbana, Cerrado, Leguminosae, Paisagismo, Palinologia

\section{Introduction}

Fabaceae is a family of herbaceous, shrubby, arboreal and climbing plants with cosmopolitan distribution and includes about 751 genera and 19.500 species. It represents the third largest family of angiosperms having great ecological and economic importance (LPWG 2013, Souza \& Lorenzi 2012). In Brazil, it is represented by about 215 genera and 2.793 species occurring in all plant formations (Flora do Brasil 2020).
The Fabaceae species deposited in the Mandevilla sp Herbarium at the Centro Universitário de Patos de Minas (UNIPAM) come from the landscape area of the University Campus and also from the urban perimeter of the city of Patos de Minas (Minas Gerais State) and these specimens were not analyzed palynologically so far. These species are exotic and native to the Cerrado and they are used for ornamentation (Dias \& Bitar 2014).

The family has a considerable diversity in the morphology of pollen grains and is considered

1. Parte do Trabalho de Conclusão de Curso do primeiro Autor

2. Instituto de Botânica, Núcleo de Pesquisa em Palinologia, Avenida Miguel Stéfano, 3687, 04301-902 São Paulo, SP, Brasil

3. Universidade Federal da Paraíba, Departamento de Sistemática e Ecologia,Cidade Universitária, s/n, Castelo Branco, $58051-900$ João Pessoa, PB, Brasil

4. Centro Universitário de Patos de Minas, Coordenação de Ciências Biológicas, Major Gote, 808, 8702-054 Patos de Minas, MG, Brasil

5. Corresponding author: higor.domingues@hotmail.com 
as euripolinic. It is a useful tool in the taxonomic delimitation of tribes, subtribes and even genus (Vishnu-Mitre \& Sharma 1962).

In general, Fabaceae pollen grains can be characterized as: monads, tetrads, ditetrads to polyads, 3-colpate, 3-colporate, 3-6-porate, exine psilate, granulate, foveolate, insulate, rugulate, microreticulate, reticulate, spinulose, gemmate or striate (Erdtman 1952, Barth 1964, Barth \& Bouzada 1964, Barth \& Yoneshigue 1966, Salgado-Labouriau 1974, Barth et al. 1976, Silvestre-Capelato \& Melhem 1997, Moreti et al. 2007, Bocage et al. 2008, Lima et al. 2008).

The aim of this research is to recognize patterns of the pollen morphology of the 16 specimes of Fabaceae, deposited in the Mandevilla sp. Herbarium at UNIPAM, whose results will help in their taxonomic delimitation and knowledge of local pollen flora.

\section{Material and methods}

We studied the pollen grains of 16 species, belonging to the Fabaceae family in Patos de Minas, Minas Gerais, Brazil. The botanical material was collected from exsiccates deposited in the Herbário Mandevilla sp. do UNIPAM (PA).

The pollen grains were prepared according to Erdtman (1960) acetolysis. The main axis (Polar Axis and Equatorial Axis in Equatorial view to monades pollen grains and Major Axis or Axis I and Minor Axis or Axis II to pollyads pollen grains) were measured in 25 pollen grains taking at random, which were averaged (x), with the standard deviation pattern (sx), the sample deviation standard (s), the coefficient of variation (V) and the confidence interval (C.I.) to $95 \%$. It was realized ten (10) measurements for the apertures and the exine layers, then it was calculated the arithmetic mean (x). The description was made according to Barth and Melhem (1988) and Punt et al. (2007) palynological glossary. The scanning electron microscopy (SEM) illustration was made in acetolysed pollen grains. The microscope slides were deposited in the Palinoteca do Núcleo de Pesquisa em Palinologia do Instituto de Botânica - SP and in the Herbarium Mandevilla sp. - UNIPAM.

\section{Results}

The Fabaceae pollen grains species show three major pollen types according to it dispersal unit: Type 1. monads; Type 2. tetrads and Type 3. polyads. The tables show the morphometric characters of pollen grains of the species in monads (table 1), tetrads and polyads (table 2).

Type 1. Monads

\section{Bauhinia L.}

Bauhinia variegata $L$ (figures. 1-3, 55-56)

Pollen grains are large; isopolar; triangular amb, prolate-spheroidal; 3-colporate, long and wide colpori covered by granular membrane, lalongate endoapertures, delimitated by margin; striatereticulate exine, large striae (figure 3), sexine thicker than nexine.

Material examined: BRASIL. MinAs GERAIS: Patos de Minas, urban area, Caiçaras district, 20-III-2013, Correa \& Antonio-Domingues s.n. (PA144.1.1).

\section{Caesalpinia L.}

Caesalpinia echinata Lam. (figures 4-6, 55-56), Caesalpinia pulcherrima (L.) Sw. (figures 7-9, 55-56).

Pollen grains are large, isopolar, circular amb, suboblates ( $C$. echinata) to oblate-spheroidal $(C$. pulcherrima); 3-colporate, brevicolporate, narrow colpi covered by granular membrane, endoaperture which is difficult to visualize (figure 5,8 ). The apertural area is united across the poles $(C$. pulcherrima), formed by a thinning of sexine, that becomes thicker again in the colpi outline causing a large depression and a very wide margin with pilate-rugulate ornamentation. It is observed on the outline of this wide margin a thickening of sexine forming a narrow thick margin. Reticulate, heterobrochate exine, simplicolumellate, baculate lumina, with smaller reticules at the poles and larger in the equatorial area (figure 9), sexine thicker than nexine, subdivided into nexine 1 and nexine 2 .

Material examined: Caesalpinia echinata Lam. BRASIL. Minas Gerais: Patos de Minas, Urban area, Rosario Square, 21-XI-2012, Cunha et al. s.n. (PA144.5.1). Caesalpinia pulcherrima (L.) Sw. BRASIL. Minas Gerais: Patos de Minas, urban area, Caiçaras district, 22-X-2012, Dias et al. s.n. (PA144.2.1).

\section{Cassia L.}

Cassia grandis L.f. (figures 10-12, 55-56)

Pollen grains small (37\%) to medium (63\%); isopolar; circular amb; oblate-spheroidal; 3-colporate; long and 


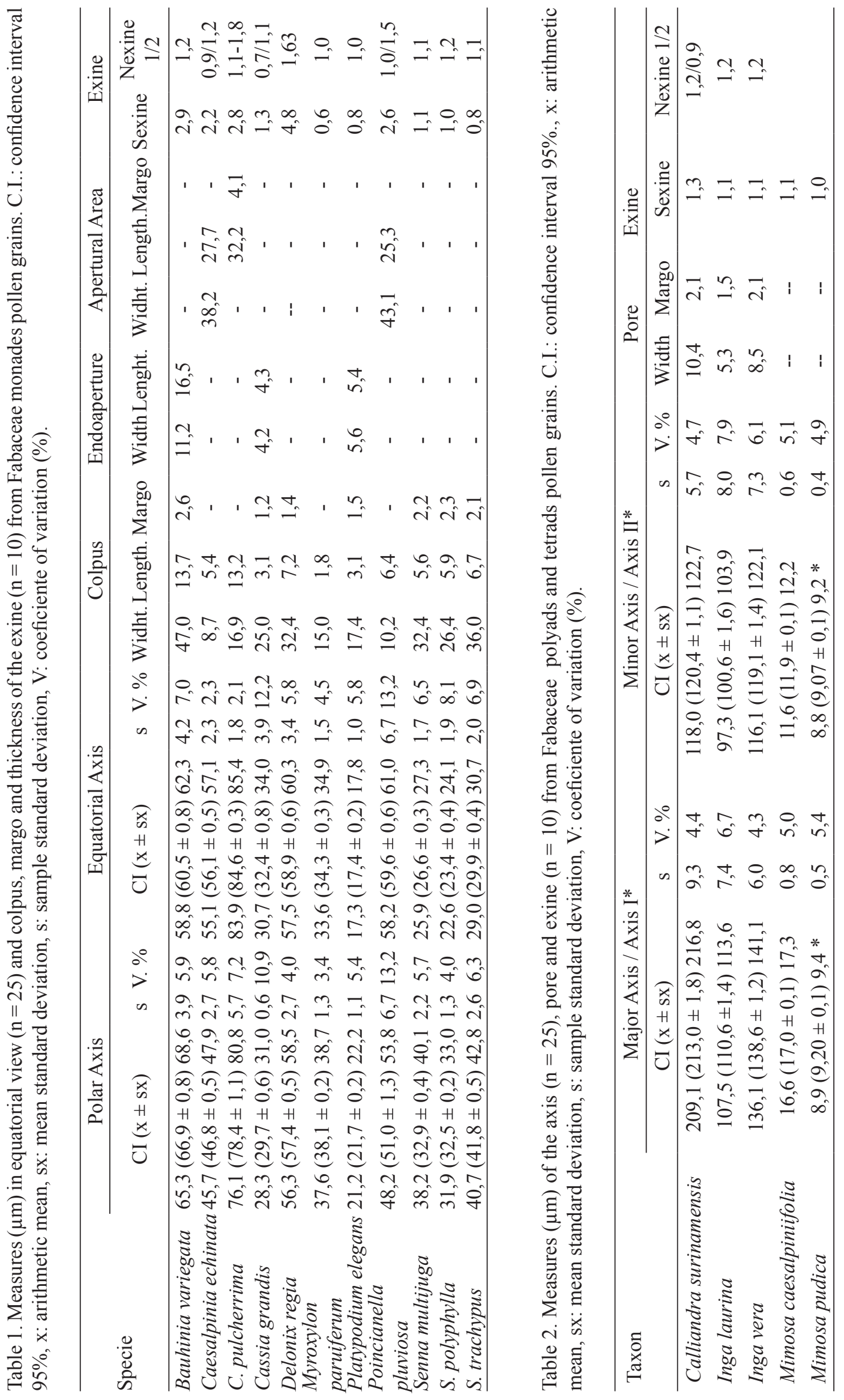


narrow colpi, with a central constriction; with pointed termination, presenting a distinct thin margin, lalongate endoaperture, with pointed apices and thin margin; rugulate-reticulate exine (figure 12); nexine thicker than sexine. Nexine subdivided into nexine 1 and nexine 2.

Material examined: BRASIL. Minas GeraIs: Patos de Minas, UNIPAM Campus I, 24-X-2012, Bitar \& Antonio-Domingues s.n. (PA144.3.1).

\section{Delonix Raf.}

Delonix regia (Bojer ex Hook.) Raf. (figures 13-15, 55-56)

Pollen grains are large; circular amb; oblatespheroidal; 3-colporate, long and wide colpi, covered by granular membrane (figure 14); lalongate endoaperture which is difficult to
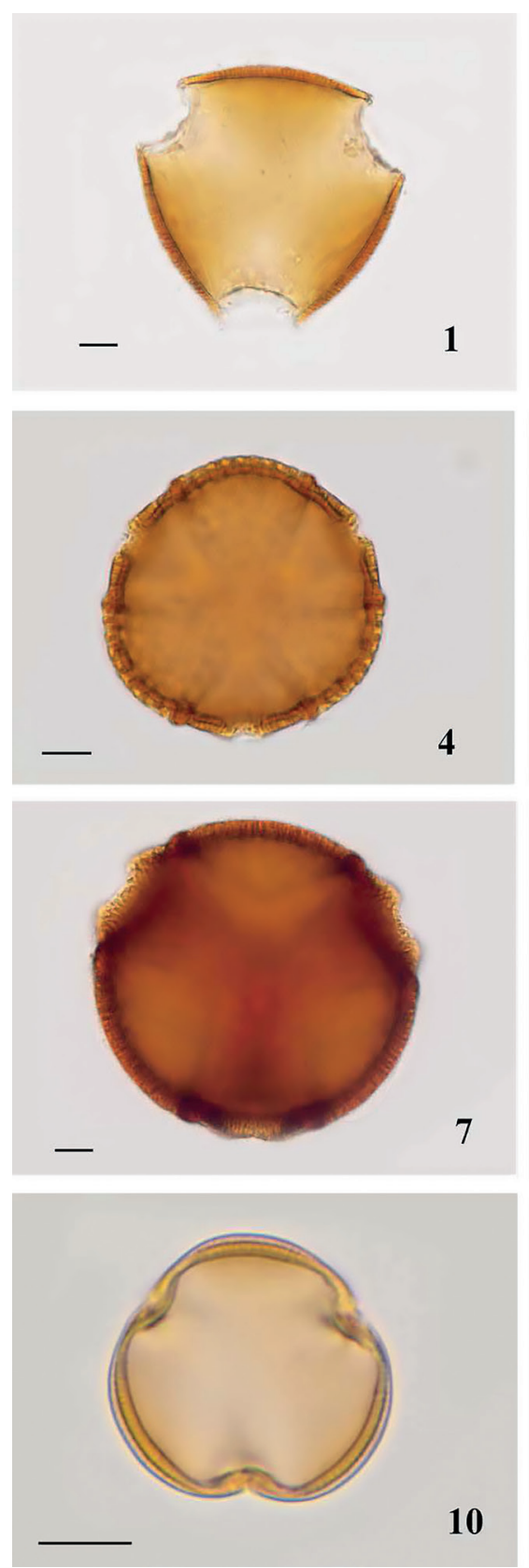
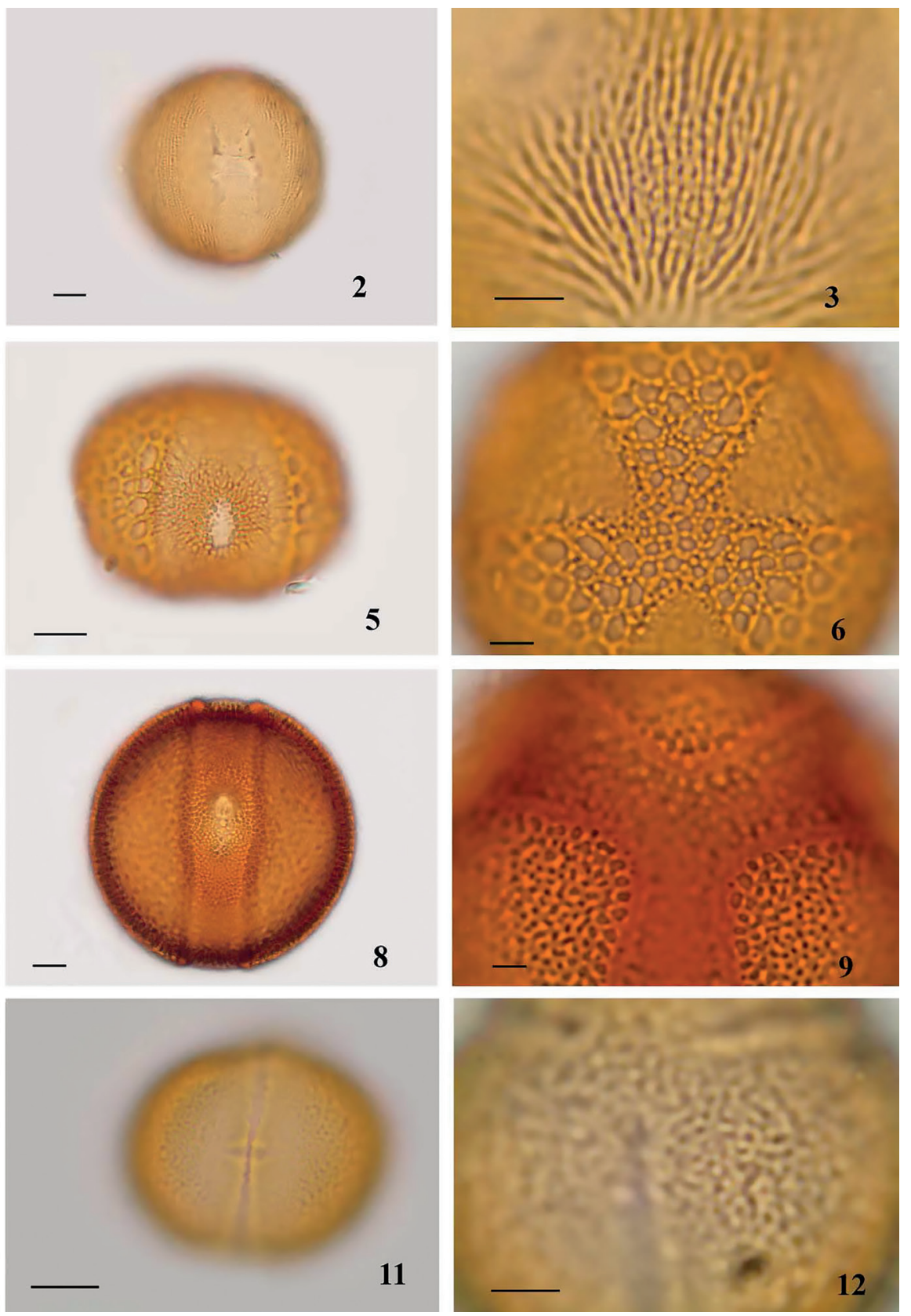

Figures 1-12 Light micrographs of Fabaceae pollen grains. 1-3. Bauhinia variegata L. 1. Optical section, polar view. 2. Equatorial view showing the colporus. 3. Exine surface. 4-6. Caesalpinia echinata Lam. 4. Optical section, polar view. 5. Equatorial view showing the colpus. 6. Exine surface. 7-9. C. pulcherrima (L.) Sw. 7. Optical section, polar view. 8. Equatorial view showing the colporus. 9. Exine surface and the apertural area united across the poles. 10-12. Cassia grandis L.f. 10. Optical section, polar view. 11. Equatorial view showing the colporus. 12. Exine surface. Bars $5 \mu \mathrm{m}(3,6,12) ; 10 \mu \mathrm{m}(1,2,4,5,7-11)$. 
visualize; reticulate, heterobrochate, retipilate exine, walls are formed by large single pila, lumen rounded shape with pila inside (figure 15); sexine thicker than nexine.

Material examined: BRASIL. Minas Gerais: Patos de Minas, UNIPAM Campus I, 11-X-2012, AntonioDomingues s.n. (PA144.9.1).

\section{Myroxylon L.f.}

Myroxylon peruiferum L. f. (figures 16-18, 55-56)

Pollen grains are medium; subcircular amb; prolate-spheroidal; 3-colporate, long and wide colpori; with margin and pointed apices; lalongate endoaperture with margin (figure 17); rugulate exine
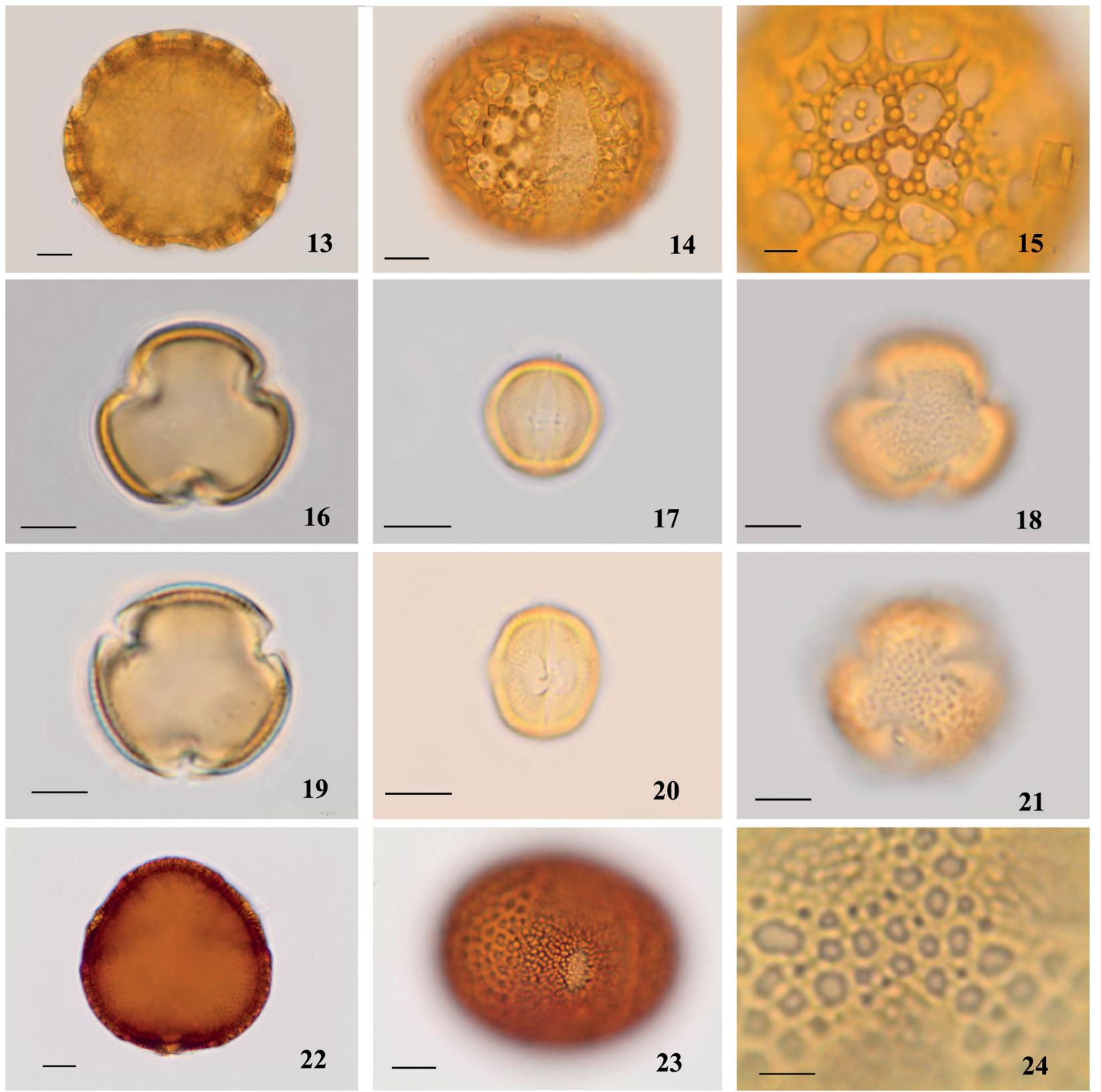

Figures 13-24. Light micrographs of Fabaceae pollen grains. 13-15. Delonix regia (Bojer ex Hook.) Raf. 13. Optical section, polar view. 14. Equatorial view showing the colporus and the endoaperture lalongate. 15. Exine surface. 16-18. Myroxylon peruiferum L. f. 16. Optical section, polar view. 17. Equatorial view showing the colporus. 18. Exine surface. 19-21. Platypodium elegans Vogel. 19. Optical section, polar view. 20. Equatorial view showing the colporus. 21. Exine surface. 22-24. Poincianella pluviosa (DC.) L.P. Queiroz. 22. Optical section, polar view. 2.3. Equatorial view showing the colpus. 24. Exine surface. Bars $5 \mu \mathrm{m}(15,16,18,19,21,24) ; 10 \mu \mathrm{m}(13$, $14,17,20,22,23)$. 
(figure 18). Nexine thicker than sexine.

Material examined: BRASIL. Minas Gerais: Patos de Minas, UNIPAM Campus I, 10-IX-2013, Cunha et al. s.n. (PA144.8.1).

\section{Platypodium Vogel}

Platypodium elegans Vogel (figures 19-21, 55-56)

Pollen grains are small; isopolar; circular amb; subprolate; 3-colporate; with a very visible lalongate endoaperture, with a central constriction, with rounded and attached apices (figure 20); reticulate exine, heterobrochate (figure 21), nexine thicker than sexine. Material examined: BRASIL. MINAS GERAIS: Patos de Minas, UNIPAM Campus I, 24-X-2013, Bitar \& Antonio-Domingues s.n. (PA144.7.1).

\section{Poincianella Britton \& Rose}

Poincianella pluviosa (DC.) L.P. Queiroz (figures 22-24, 55-56)

Pollen grains are large; isopolar, circular amb; suboblate; 3-brevicolpate; narrow colpi covered by a granular membrane. Apertural area formed by a thinning of sexine that becomes thicker again in the colpi outline causing a large depression and a very wide margin with pilate-rugulate ornamentation (figures 22, 23). It is observed on the outline of this great margin a thickening of sexine forming a narrow thick margin; reticulate, heterobrochate, simplicolumellate exine (figure 24), reticulum smaller towards the poles and larger on the equatorial area, bacula inside the lumem; sexine thicker than nexine, subdivided into nexine 1 and nexine 2 .

Material examined: BRASIL. Minas Gerais: Patos de Minas, UNIPAM Campus I, 22-X-2012, Dias et al. s.n. (PA144.4.1).

\section{Senna Mill.}

Senna multijuga (Rich.) H.S. Irwin \& Barneby (figures 25-27, 55-56), Senna polyphylla (Jacq.) H.S. Irwin \& Barneby (figures 28-30, 51-54, 5556), Senna trachypus (Mart. ex Benth.) H.S. Irwin $\&$ Barneby (figures 31-33, 55-56)

Pollen grains are medium, circular amb $(S$. multijuga), subtriangular (S. trachypus) to triangular (S. polyphylla), prolate (S. multijuga), prolate to prolate-spheroidal ( $S$. polyphylla, S. trachypus); 3-colporate, long, wide colpi, with rounded apices, thick margin and central constriction, endoaperture which is difficult to visualize; rugulate-perforate exine surface; sexine is thicker than nexine. Under the SEM (S. polyphylla), observed on the polar view the large colpori (figure 51); detail of colporus with a medium constriction and covered by granular membrane (figures 52, 53) and detail of the exine ornamentation rugulate-perforate (figure 54).

Material examined: Senna multijuga (Rich.) H.S. Irwin \& Barneby. - BRASIL. Minas Gerais: Patos de Minas, UNIPAM Campus I, XII-2011, Bitar \& Dias s.n. (PA144.13.1). Senna polyphylla (Jacq.) H.S. Irwin \& Barneby - BRASIL. Minas Gerais: Patos de Minas, UNIPAM Campus I, 19-X-2012, Dias et al. s.n. (PA144.14.1). Senna trachypus (Mart. ex Benth.) H.S. Irwin \& Barneby - BRASIL. MinAs GeraIs: Patos de Minas, UNIPAM Campus I, 31-I-2014, AntonioDomingues \& Nogueira s.n. (PA144.17.1).

Type 2. Tetrads

\section{Mimosa L.}

Mimosa pudica L. (figures 34, 57)

Pollen grains are unites in tetraedrics tetrads, spheroidal, small and acalimate; 12-porates each pollen grain has three pore; psilate exine; nexine and sexine indistinct, which makes impossible to measure each one of them separately.

Material examined: Mimosa pudica L. - BRASIL. Minas Gerais: Patos de Minas, Afonso de Queiroz Agricultural school, VI-2013, Antonio-Domingues et al. s.n. (PA144.15.1).

Type 3. Polyads

\section{Calliandra Benth.}

Calliandra surinamensis Benth. (figures 35-37, 46, $47,57)$

Pollen grains united in very large, uniplanar, calymmate, oval and asymetric polyads, composed by eight pollen grains, two of them are central and the other six are peripheral, 4-(5)-porate. These pores are located in the angle formed by the junction of three pollen grains in the polyad, with distinct margin (figure 35). The apical pollen grain without appendix, 
with a pore on its end. Exine rugulate, nexine thicker than sexine. The nexine is subdivided into nexine 1 and nexine 2. Under the SEM, it is observed through the general view Calliandra surinamensis (figure 46) polyad and detail of the rugulate exine ornamentation (figure 47).

Material examined: BRASIL. Minas Gerais: Patos de Minas, urban area, Jardim Paraiso district, V-2014, Antonio-Domingues s.n. (PA144.16.1).

\section{Inga Mill.}

Inga laurina (Sw.) (figures 38-40, 48- 49, 57), Inga vera Willd. (figures 41-43, 50, 57)

Pollen grains unit on acalymmate polyads; form circular (I. laurina) to elyptic (I. vera); very large; composed of 16 pollen grains (I. laurina), eight of them are central, and the other eight are peripherals (figure 38), the eight central pollen grains are organized in two plans each one with four pollen grains; or composed by 24 pollen grains (figure 42), which 12 of them are centrals and the others 12 are peripherals (Inga vera). The 12 centrals pollen grains are organized in two plans each one with six pollen grain, with 4 or 6 pores in each pollen grain. Areolate exine, nexine is thicker than sexine. Under SEM, through the general view of I. laurina polyad showing it shows four centrals pollen grains and eight peripherals (Figure 48). Under the SEM, it is displayed an areolate ornamentation of the $I$. vera (Figura 49, 50).

Material examined: Inga vera Willd. BRASIL. Minas Gerais: Patos de Minas, UniPAM Campus I, 10-III-2014, Antonio-Domingues s.n. (PA144.20.1). Inga laurina (Sw.) Willd. BRASIL. Minas Gerais: Patos de Minas, UNIPAM Campus I, 31-I-2014, Antonio-Domingues \& Nogueira s.n. (PA144.18.1).
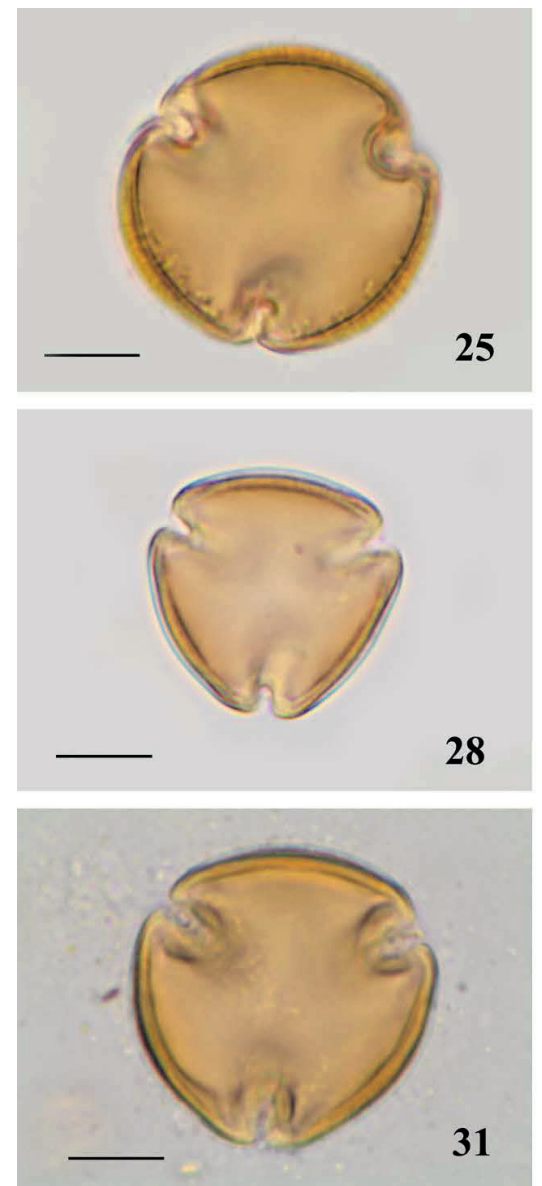
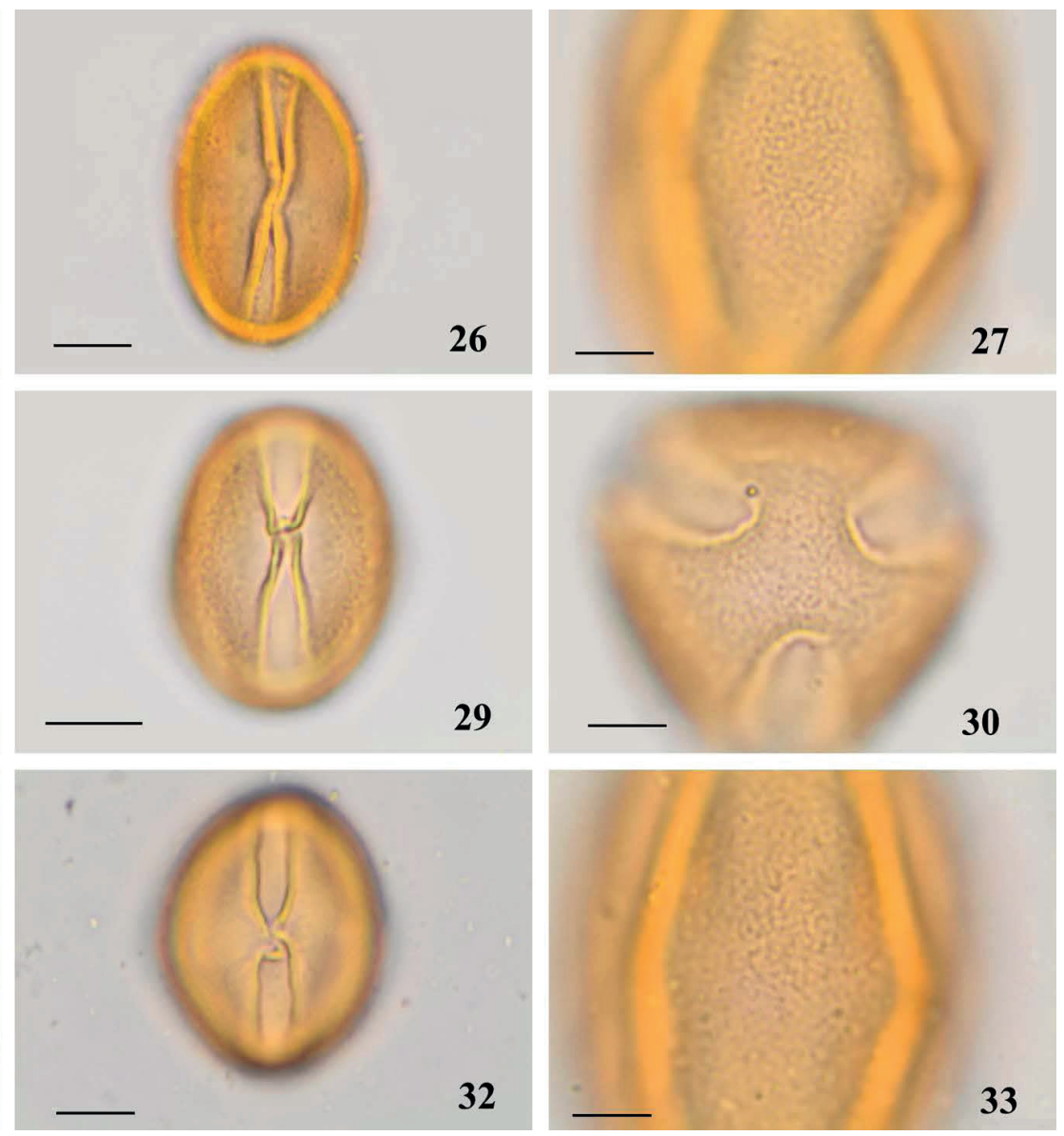

Figures. 25-33. Light micrographs of Senna Mill. (Fabaceae) pollen grains. 25-27. S. multijuga (Rich.) H.S. Irwin \& Barneby. 25. Optical section, polar view. 26. Equatorial view showing the colporus. 27. Exine surface. 28-30. S. polyphylla (Jacq.) H.S. Irwin \& Barneby. 28. Optical section, polar view. 29. Equatorial view showing the colporus. 30. Exine surface. 31-33. S. trachypus (Mart. ex Benth.) H.S. Irwin \& Barneby. 31. Optical section, polar view. 32. Equatorial view showing the colporus. 33. Exine surface. Bars $5 \mu \mathrm{m}(27,30,33)$; $10 \mu \mathrm{m}(25,26,28,29,31,32)$. 
Mimosa L.

Mimosa caesalpiniifolia Benth. (figures 44, 45, 57)

Pollen grains are unites in small polyads, acalymates, composed of eight pollen grains on ditetrads assembled in two tetragonal tetrads 24-porate, each pollen grain has three pore; granulate exine; nexine and sexine indistinct, which makes impossible to measure each one of them separately.

Material examined: Mimosa caesalpiniifolia Benth. BRASIL. Minas Gerais: Patos de Minas, UNIPAM Campus III - Integrar, 9-IV-2013, Bitar et al. s.n. (PA144.12.1).
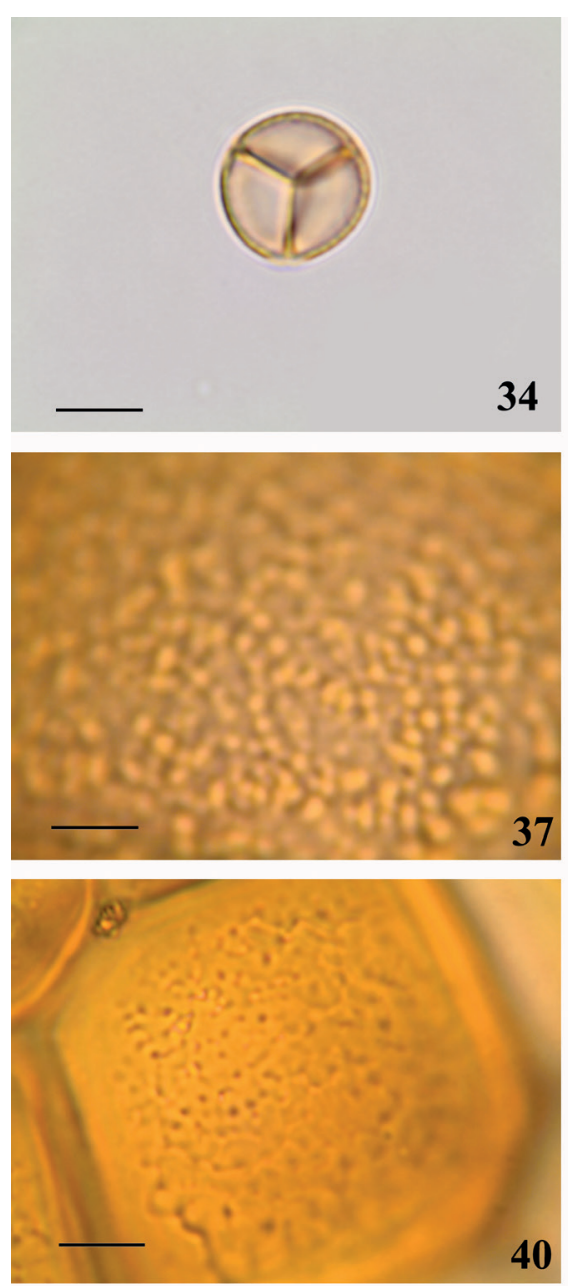

40

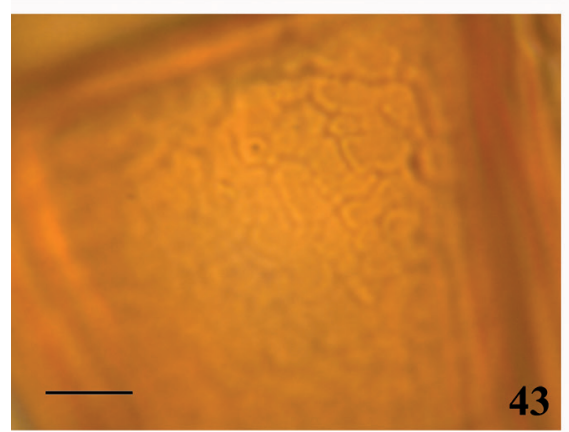

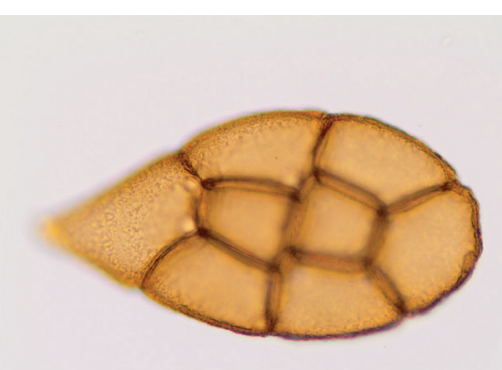

35

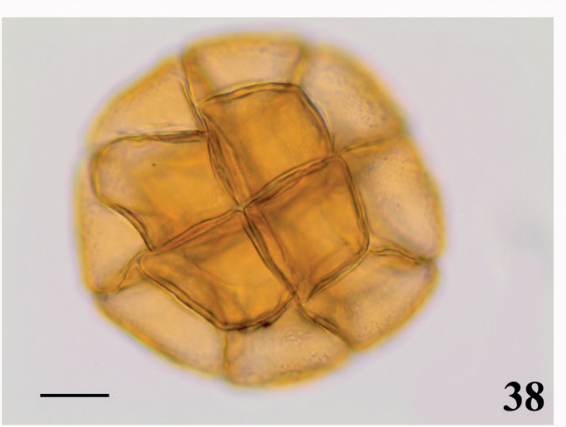

38
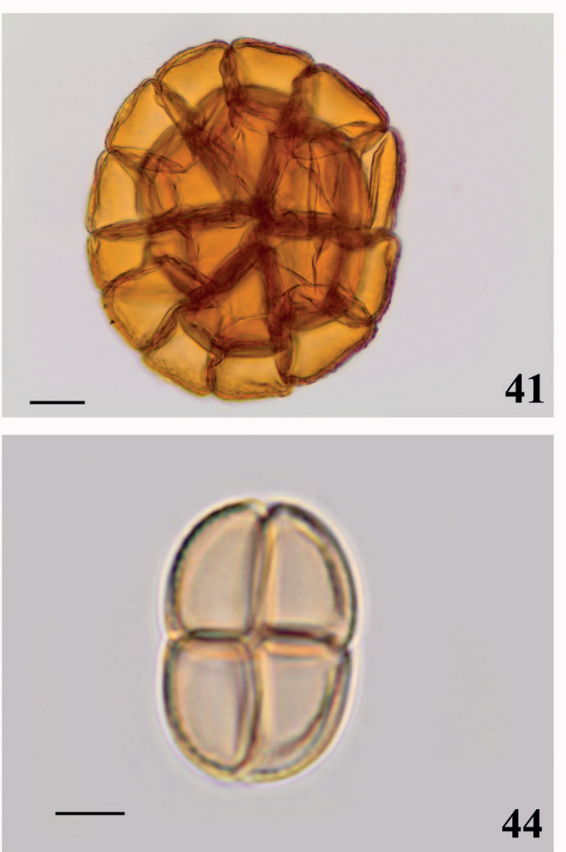
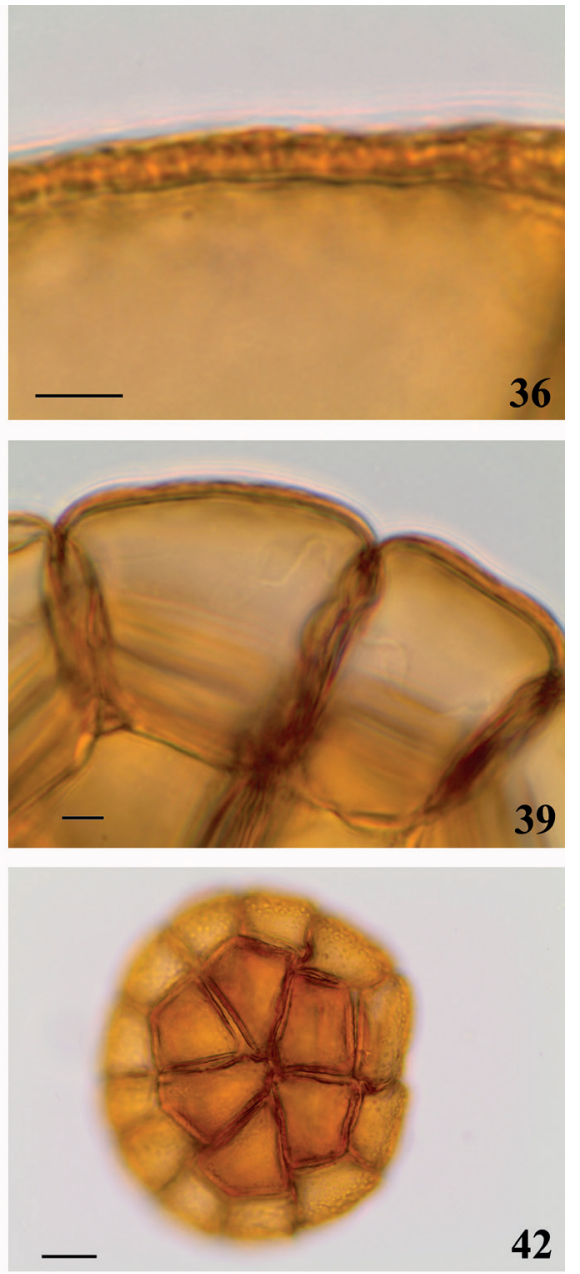

42

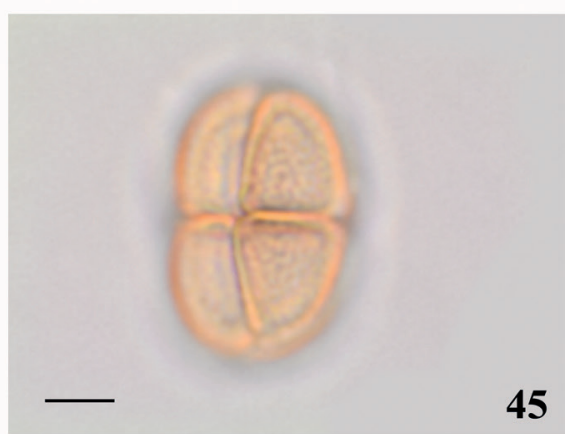

Figures 34-45. Light micrographs of Fabaceae pollen grains. 34. Mimosa pudica L. Tetraedric tetrad outline. 35-37. Calliandra surinamensis Benth. 35. Frontal view of the polyad. 36. Exine optical section. 37. Exine surface. 38-40. Inga laurina (Sw.). 38. Frontal view of the polyad, showing the four central pollen grains. 39. Exine optical section. 40. Exine surface. 41-43. Inga vera Willd. 41 . Polyad outline. 42. Frontal view of the polyad, showing the six central pollen grains. 43. Exine surface. 44-45. Mimosa caesalpiniifolia Benth. 44. Ditetrad outline. 45. Exine surface. Bars $5 \mu \mathrm{m}(34,36,37,39,40,42) ; 10 \mu \mathrm{m}(44,45) ; 20 \mu \mathrm{m}(35,38,41,42)$. 
The quantitative data analysis

The $95 \%$ Confidence Interval (CI) of monad pollen grains (figure 55, 56) showed that (A) Platypodium elegans, Delonix regia, Bauhinia variegata and Caesalpinia pulcherrima are apart from the others species, for bearing the smallest pollen grains in the first species and the largest in the three later species, considering the polar and equatorial axis. (B) the other species, when analysed in the polar and equatorial axis (figures 55, 56) gathering in three distinct groups: group 1. (Cassia grandis, Senna polyphylla), group 2. (Myroxylon paruiferum, Senna multijuga, Senna trachypus), group 3. (Caesalpinia echinata, Poincianella pluviosa) which the pollen grains of each group cannot be separated from each other but are separated between groups. Analysing the major axis of the tetrads and polyads species (figure 57) shows that all species are separated from each other.
Mimosa pudica and Mimosa caesalpinifolia species have the lowest values and Calliandra suranimensis the largest one.

\section{Discussion}

This study is the beginning of research in the Patos de Minas city with the pollen grains and a start point of a palynological collections with representants from a Cerrado restricted Brazilian area, until now not known.

The species analyzed here in monads presented variations concerning the apertures and the exine ornamentation. Bauhinia variegata is an exotic species, widely cultivated as ornamental in Brazil (Souza \& Lorenzi 2012). The palynological results obtained by Larsen (1975) and Perveen \& Qaiser (1998) corroborate with that of the specimen analyzed here. However, the Brazilian species of Bauhinia described by Barth \& Bouzada (1964), Salgado-
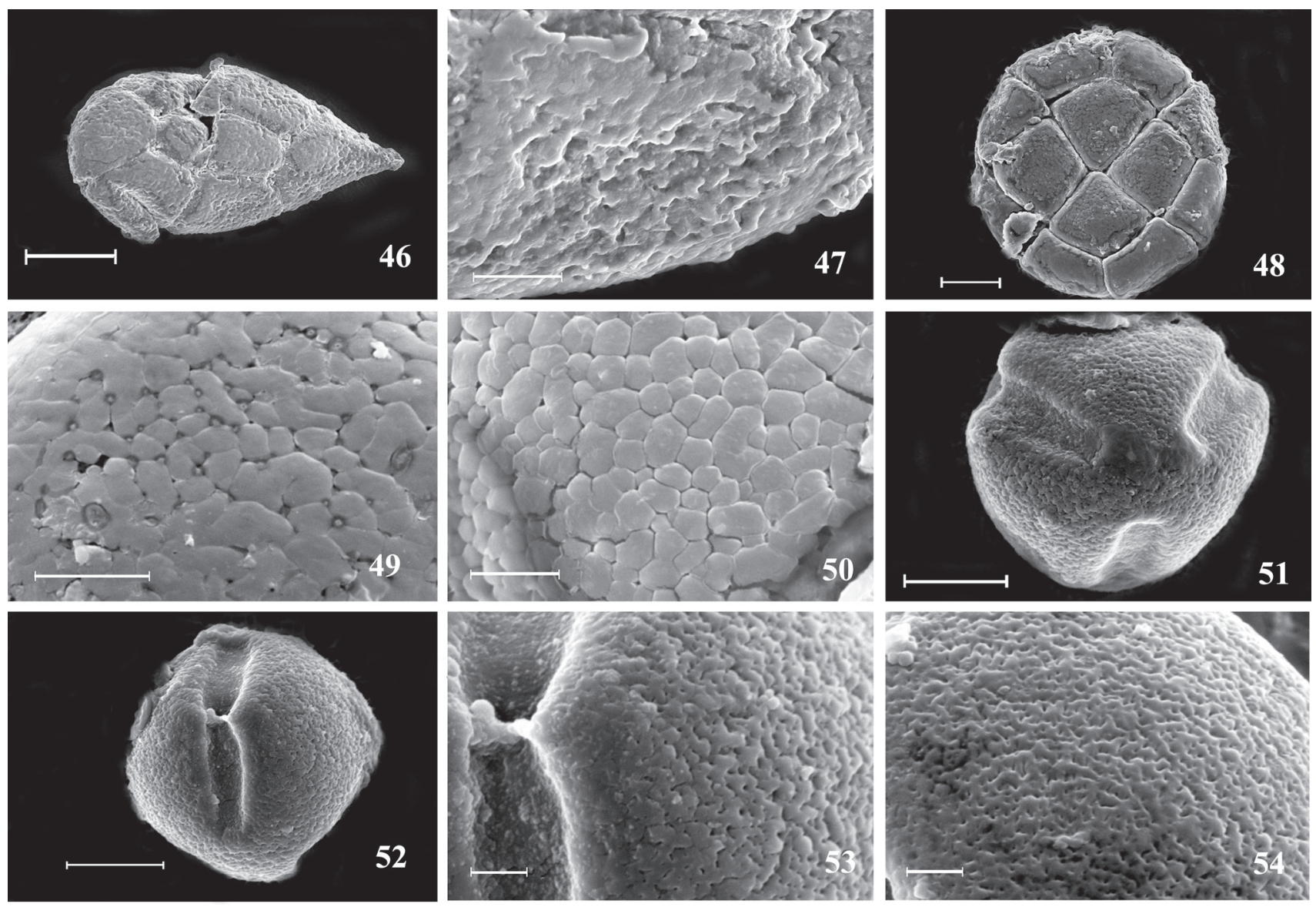

Figures 46-54. Scanning electron micrograph of Fabaceae pollen grains. 46-47. Calliandra surinamensis Benth. 46. Frontal view of the polyad. 47. Exine surface. 48-49. Inga laurina (Sw.) Willd. 48. Frontal view of the polyad. 49. Exine surface. 50. Inga vera Willd. Exine surface. 51-54 Senna polyphylla (Jacq.) H.S. Irwin \& Barneby. 51. Polar view. 52. Colporus with central constriction, equatorial view. 53. Detail of central constriction and exine surface. 54. Exine surface. Bars $2 \mu \mathrm{m}(53,54) ; 5 \mu \mathrm{m}(49,50) ; 10 \mu \mathrm{m}(47,51,52) ; 20 \mu \mathrm{m}$ (48); $50 \mu \mathrm{m}(46)$. 


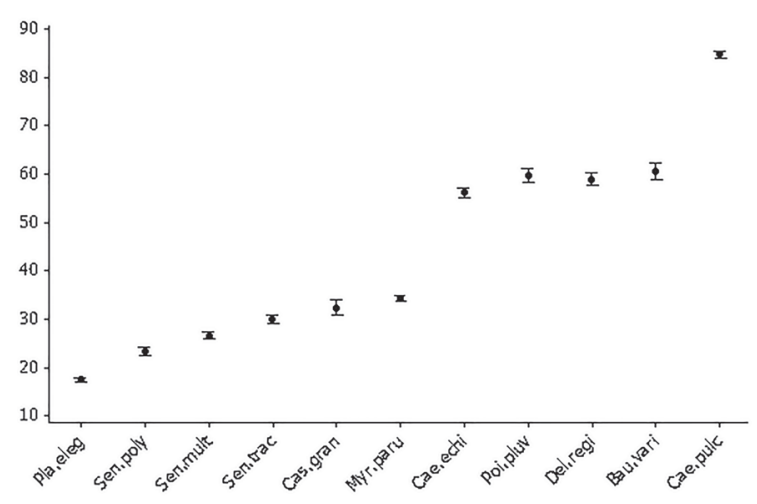

Figure 55. Representation of the Confidence Interval at 95\% of equatorial diameter in equatorial view in the species with monads pollen in Fabaceae. $(\mathrm{n}=25)$. Platypodium elegans (Pla.eleg), Cassia grandis (Cas.gran), Senna polyphylla (Sen.poly), Myroxylon paruiferum (Myr.paru), Senna multijuga (Sen.mult), S. trachypus (Sen.trac), Caesalpinia echinata (Cae.echi), Poincianella pluviosa (Poi.pluv), Delonix regia (Del.regi), Bauhinia variegata (Bau.vari) and Caesalpinia pulcherrima (Cae.pulc).

Labouriau (1974), Carreira et al. (1996), Moreira et al. (2013), Buril et al. (2010), Santos et al. (2012) present exine gemmate, clavate, verrucate with microreticulate tectum, showing a difference among native and exotic species and that the genus is eurypalynous.

The two species of the genus Caesalpinia L. analyzed here are distinguished by the types of apertures, and $C$. pulcherrima presents an apertural area joined at the poles and $C$. echinata not joined at the poles. In studies carried out by Perveen and Qaiser (1998), C. pulcherrima was described as 3-parasincolporate, but the structure defined as colpus by this author was described here as being the result of a thinning of the sexine in the apertural area. For C. echinata, Corrêa (2003) described the pollen grains of the species as having an aperural area not joined at the poles as those of the present study.

Abdalla and El Ghazali (2014), who studied, pollen grains of Cassia grandis presented results that corroborate with those analyzed here regarding the size of the pollen grains and the type of aperture, but diverged with respect to the exine ornamentation described by them as psilate-microreticulate. Palynological studies for Myroxylon peruiferum have so far not been found in the literature, however when analyzing the pollen grains of M. balsamum (L.) Harms, Carreira et al. (1996) defined the exine ornamentation as psilate.

The pollen grains of Delonix regia were studied by Jumah (1991-96a) and Carreira et al. (1996).

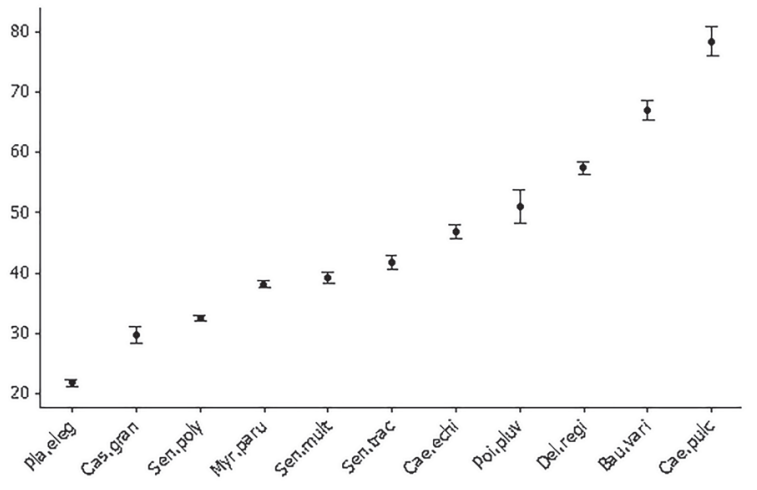

Figure 56. Representation of the confidence interval at $95 \%$ of the polar diameter in equatorial view in the species with monads pollen in Fabaceae. Platypodium elegans (Pla.eleg), Senna polyphylla (Sen.poly), Senna multijuga (Sen.mult), S. trachypus (Sen.trac), Cassia grandis (Cas.gran), Myroxylon paruiferum (Myr.paru), Caesalpinia echinata (Cae.echi), Poincianella pluviosa (Poi. pluv), Delonix regia (Del.regi), Bauhinia variegata (Bau.vari) and Caesalpinia pulcherrima (Cae.pulc).

The results presented by these authors differ from themselves and from this current study. Mainly in the ornamentation exine that has been described as roughly reticulate by Jumah (1991-96a) and foveolate by Carreira et al. (1996).

The Senna species studied here are also characterized as stenopalynous by a number of authors (Carreira et al., 1996, Silvestre-Capelato \& Melhem 1997, Perveen \& Qaiser 1998, Buril et al., 2011, Leal et al. 2011; Luz et al. 2013) who analyzed other species of the genus confirming the results presented here. The results showed that these are generally 3-colporate, sometimes parasincolporate and with exine described as reticulate, microreticulate, rugulatefossulate, fossulate-foveolate, perforate to rugulate.

Carreira et al. (1996) analyzed the pollen grains of Platypodium elegans whose results are similar to those of the specimen analyzed here.

Poincianella, a segregated genus of Caesalpinia (Queiroz 2009), is represented in this research by P. pluviosa whose pollen grains present a "Caesalpinia" type aperture with an apertural area characteristic of the genus, a character also corroborated by Zaia (2004) when studying the species under the name of Caesalpinia peltophoroides Benth., one of its synonyms.

According to Sorsa (1969), pollen grains joined in tetrad and polyads are the main characteristic for the palynological classification of the Clado Mimosoidea that occurred in the present study. Thus, the polyads 


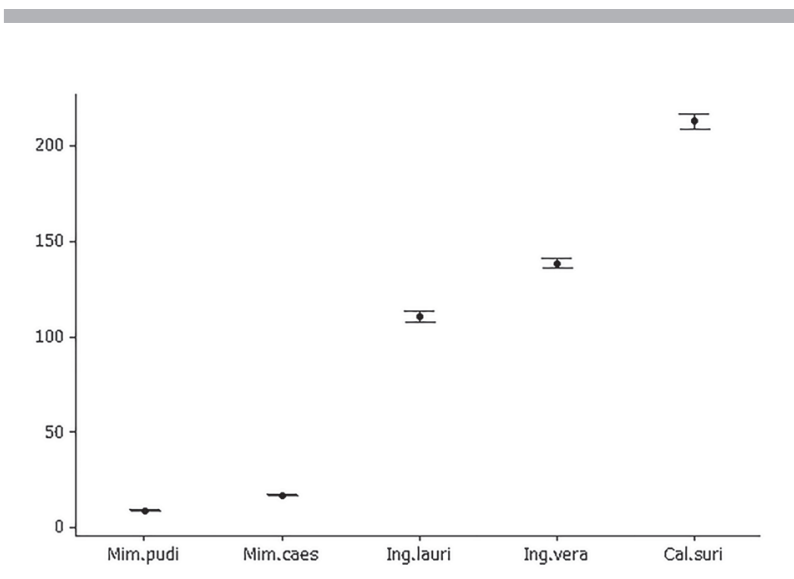

Figure 57. Representation of the confidence interval at $95 \%$ of the major axis in polyads and tetrads in Fabaceae $(\mathrm{n}=25)$. Mimosa pudica (Mim.pudi), M. caesalpiniifolia (Mim.caes), Calliandra surinamensis (Cal.suri), Inga laurina (Ing.laur) and I. vera (Ing. vera).

of Calliandra surinamensis described by Jumah (1991-96b) presents granular sexine, basal appendix and smaller octads, diverging from the specimen analyzed here, because it presents rugulate sexine, with no basal appendix and larger octades.

It was possible to distinguish the Inga laurina species by having 16 grains of Inga vera pollen with 24. Taizma (2013), when analyzing the I. laurina polyads which found results similar to those of the present study. Buril et al. (2010) and Taizma (2013) studied $I$. vera whose results corroborated with each other, but diverged from the present study since for these authors the species presented polyads consisting of 16 pollen grains.

The Mimosa species studied here ( $M$. caesalpiniifolia, M. pudica) are significantly different as to their dispersion unit. Mimosa caesalpiniifolia presents polyads, formed by eight pollen grains in ditratrades while $M$. pudica presents tetrahedral tetrads, whose results corroborate with the studies of Lima et al. (2008).

Concerning the quantitative data shown in figures 55,56 and 57 they were relatively significant for the distinction of some species of monads and Platypodium elegans and Caesalpinia pulcherrima presented smaller and larger pollen grains, respectively. The other species interpose forming continuous with each other. The Caesalpinia echinata quantitative data shows that they have pollen grains significantly smaller than the Caesalpinia pulcherrima. The quantitative data shows that Senna polyphyla presents the lower pollen grains than Senna multijuga and Senna trachypus. For the tetrads and polyads, the
Mimosa species formed a group with the smallest pollen grains and Calliandra with the largest ones. The confidence interval of $95 \%$ showed that Inga laurina separates from Inga vera for having smaller pollen grains. The quantitative and qualitative data with de palynological literature showed that the Fabaceae is euripalinous family.

\section{Acknowledgments}

We thank the Fundação Educacional de Patos de Minas - FEPAM (without processes number) for financial support, scholarship funding and internship to the first author in the visit the Núcleo de Pesquisa em Palinologia - Instituto de Botânica.

\section{Literature cited}

Abdalla, W.E. \& Ghazali, G.E.B.E. 2014. Pollen Morphological Study on the Genus Cassia L. sensu stricto from Sudan. Australian Journal of Basic and Applied Sciences 8: 436-443.

Barth, O.M. 1964. Catalogo Sistemático dos Pólens das Plantas Arbóreas do Brasil Meridional: V Leguminosae: Papilionatae. Memórias do Instituto Oswaldo Cruz 62: 95-123.

Barth, O.M. \& Bouzada, C.P. 1964. Catálogo Sistemático dos Pólens das Plantas Arbóreas do Brasil Meridional: VI - Leguminosae: Caesalpinioideae. Memórias do Instituto Oswaldo Cruz 62: 169-192.

Barth, M.O. \& Melhem, T.S. 1988. Glossário ilustrado de palinologia. Editora Universidade Estadual de Campinas, Campinas.

Barth, O.M. \& Yoneshigue, Y. 1966. Catálogo Sistemático dos Pólens das Plantas Arbóreas do Brasil Meridional: VIII - Leguminosae: Mimosoideae. Memórias do Instituto Oswaldo Cruz 64: 79-111.

Barth, O.M., Corte-Real, S. \& Macieira, E.G. 1976. Morfologia de Pólen Anemófilo e Alergizante: II . Polygonaceae, Amaranthaceae, Chenopodiaceae, Leguminosae, Euphorbiaceae e Myrtaceae. Memórias do Instituto Oswaldo Cruz 74: 191-201.

Bocage, A.D., Souza, M.A., Miotto, S.T.S. \& GonçalvesEsteves, V. 2008. Palinotaxonomia de Espécies de Acacia (Leguminosae-Mimosoideae) no Semi-Árido. Brasileiro. Rodriguésia 59: 587-596.

Buril, M.T., Santos, F.A.R. \& Alves, M. 2010. Diversidade polínica das Mimosoideae (Leguminosae) ocorrentes em uma área de Caatinga, Pernambuco, Brasil. Acta Botanica Brasilica 24: 53-64.

Buril, M.T., Alves, M. \& Santos, F.A.R. 2011. Tipificação polínica em Leguminosae de uma área prioritária para conservação da Caatinga: Caesalpinioideae e Papilionoideae. Acta Botanica Brasilica 25: 699-712. 
Carreira, L.M.M., Silva, M.F., Lopes, J.R.C. \& Nascimento, L.A.S. 1996. Catálogo de Pólen das Leguminosas da Amazônia Brasileira. Museu Emílio Goeldi, Pará.

Corrêa, A.M.S. 2003. Morfologia polínica de Caesalpinia echinata Lam. (Leguminosae - Caesalpinioideae). Revista Brasileira de Botânica 26: 355-359.

Dias, A.A.V. \& Bitar, N.A.B. 2014. Fitossociologia da área paisagística do Centro Universitário de Patos de Minas - UNIPAM. Perquirere 11: 258-274.

Erdtman, G. 1952. Pollen morphology and plant taxonomy: angiosperms. Alquist \& Wiksell, Stockholm.

Erdtman, G. 1960. The acetolysis method. A revised description. Svensk Botanisk Tidskrift 54: 561-564.

Flora do Brasil 2020 (em construção). 2016. Jardim Botânico do Rio de Janeiro. Available in http:// floradobrasil.jbrj.gov.br/reflora/floradobrasil/FB115 (access in 18-VIII-2016).

Jumah, A. 1991-96a. Studies on the morphology of pollen grains of the Leguminosae - the Caesalpinioideae. Ghana Journal of Science 31-36: 23-28.

Jumah, A. 1991-96b. Studies on the morphology of pollen grains of the Leguminosae - the Mimosoideae. Ghana Journal of Science 31-36: 29-35.

Leal, A., Berrío, J.C., Raimúndez, E., Bilbao, B. 2011. A pollen atlas of premontane woody and herbaceous communities form the upland savanas of Guayana, Venezuela. Palynology 35: 226-266.

Lima, L.C.L., Silva, F.H.M. \& Santos, F.A.R. 2008. Palinologia de espécies de Mimosa L. (Leguminosae Mimosoideae) do Semi-Árido brasileiro. Acta Botanica Brasilica 22: 794-805.

Larsen, S.S. 1975. Pollen Morphology of Thai species of Bauhinia (Caesalpiniaceae). Grana 14: 114-131.

LPWG. 2013. The Legume Phylogeny Working Group. Taxon 62: 217-248.

Luz, C.F.P., Maki, E.S., Horák-Terra, I., Vidal-Torrado, P. \& Filho, C.V.M. 2013. Pollen grain morphology of Fabaceae in the Special Protection Area (SPA) Pauda-Fruta, Diamantina, Minas Gerais, Brazil. Anais da Academia Brasileira de Ciências 85: 1329-1344.

Moreira, F.F., Vaz, Â.M.S.F., Mendonça, C.B.F. \& Gonçalves-Esteves, V. 2013. The systematic value of pollen morphology in trees and shrubs species of Bauhinia L. (Caesalpinioideae- subg. Bauhinia - sect. Pauletia) occurring in Brazil. Acta Botanica Brasilica. 27: 400-417.
Moreti. A.C.C.C., Fonseca, T.C., Rodrigues, A.P.M., Monteiro-Hara, A.C.B.A. \& Barth, O.M. 2007. Fabaceae forrageiras de Interesse Apícola. Aspectos Botânicos e Polínicos. Boletim Científico 13: 1-98.

Perveen, A. \& Qaiser, M. 1998. Pollen Flora of Pakistan X. Leguminosae (Subfamily: Caesalpinioideae). Turkish Journal of Botany 22: 145-150.

Punt, W., Hoen, P.P., Blackmore, S., Nilsson, S. \& LeThomas, A. 2007. Glossary of pollen and spore terminology. Review of Palaeobotany and Palynology 143: $1-81$.

Queiroz, L.P. 2009. Leguminosas da Caatinga. Universidade Estadual de Feira de Santana, Feira de Santana.

Salgado-Labouriau, M.L. 1974. Contribuição à palinologia dos Cerrados. Academia Brasileira de Ciências, Rio de Janeiro.

Santos, F.A.R., Novaes, D. M. \& Queiroz, L.P. 2012. Pollen of Bauhinia L. and Phanera Lour. (LeguminosaeCaesalpinioideae) from the Brazilian Caatinga. American Journal of Plant Sciences, 7: 909-920.

Silvestre-Capelato, M.S.F. \& Melhem, T.S. 1997. Flora Polínica da Reserva do Parque Estadual das Fontes do Ipiranga (São Paulo, Brasil): Família: 81-Leguminosae. Hoehnea 24: 115-163.

Sorsa, P. 1969. Pollen morphological studies on the Mimosaceae. Annales Botanici Fennici 6: 1-34.

Souza, V.C. \& Lorenzi, H. 2012. Botânica Sistemática: guia ilustrado para identifi cação das famílias de Fanerógamas e nativas e exóticas no Brasil, baseado em APG III. 3 ed., Nova Odessa, São Paulo, Instituto Plantarum.

Taizma, M.A. 2013. Caracterización de políades en espécies venezolanas del género Inga Mill. (Fabaceae-Mimosoideae). Acta Botanica Venezuelica 36: $1-14$.

Vishnu-Mitre \& Sharma, B.D. 1962. Studies of Indian pollen grains. 1 - Leguminosae. Pollen et spores 4: 6-45.

Zaia, H.A.B.A. 2004. Desenvolvimento floral de Caesalpinia echinata Lam., Caesalpinia peltophroides Benth. e Caesalpinia ferrea var. leyotachia Benth. (Fabaceae/Caesalpinioideae). Dissertação de Mestrado. Escola Superior de Agricultura "Luiz de Queiroz", Universidade de São Paulo. 